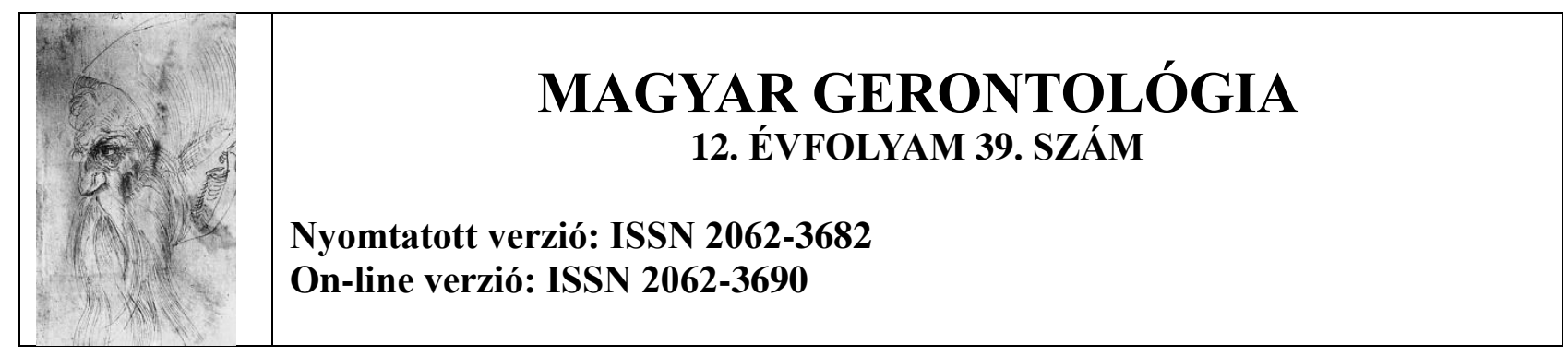

\title{
Új szerepben 70 fölött az online térben
}

\author{
Arató András \\ aratoa@gmail.com \\ elnök emeritus, Magyar Világítástechnikai Társaság
}

\begin{abstract}
Absztrakt
A cikk szerzője esettanulmányként saját példáján mutatja be, hogy egy új szerepvállalás milyen pozitív változásokat hozhat egy nyugdíjas korú ember életében. Az időskori aktivitás esetében családi örökség, édesapja 83 évesen bekövetkezett haláláig folyamatosan dolgozott szaklektorként és fordítóként, nagyapja 82 éves korában megnyert egy pályázatot, amely a korszerü fizikatanítási módszerekről szólt.

A szerző villamosmérnöki munkaköréből történt nyugdíjba vonulása után, 65 éves korában egy véletlennek köszönhetően vált az interneten főleg a fiatalok körében ismertté. Szomorkásan mosolygó fotói alapján elnevezték a fájdalmát elrejtő Hide the pain Haroldnak, és a képeiből elkezdtek vicces mémeket gyártani. Kezdetben nem fogadta el új szerepkörét, megpróbált küzdeni ellene. Több évbe telt, mire rájött, hogy amit nem tud megváltoztatni, annak az élére kell állni. 72 évesen jutott el odáig, hogy létrehozott egy saját internetes oldalt a rajongói számára, és elkezdett azon dolgozni, hogy a kezdetben nem mindig pozitív üzenetet hordozó mémeket egy követhető, pozitív életszemlélet váltsa fel. Az alapgondolat, hogy az élet kisebb-nagyobb kellemetlenségeit nem kell túl komolyan venni, egy bánatos mosollyal túl kell lépni rajtuk, visszhangra talált a fiatalok körében.

Követőinek száma világszerte már meghaladja a félmilliót, de legsikeresebb posztjai a megosztások révén tízmilliókhoz jutnak el. Az így szerzett népszerüség megváltoztatta a mindennapi életét. Meghívások révén Szibériától Dél-Amerikáig eljutott a világ számos országába, korábban inkább introvertált személyisége nyitottabbá vált a közszereplésre. A világ eseményeivel, az újabb technikai lehetőségekkel, a fiatalok gondolkodásmódjával való lépéstartás állandó elfoglaltságot jelent számára.
\end{abstract}


Története egyszeri és megismételhetetlen, de példát mutat arra, hogy egy időskori karrierváltásnak milyen pozitív következményei lehetnek.

Kulcsszavak: karrier, nyugdíjazás, Hide the pain Harold, Hide the Pain filozófia

\title{
$70+$ new role in online space
}

\begin{abstract}
As a case study, the author uses his own example to show how a new role can bring positive changes in the life of a retired person. In his case, the activity in old age is a family inheritance. His father worked as a proofreader and multi-lingual translator until he died at the age of 83. His grandfather won a competition for modern methods of teaching physics when he was 82 . After retiring as an electrical engineer, at the age of 65, the author became known on the Internet, mainly among young people. Based on his somewhat sad smile he was given the name Hide the pain Harold, the internet users started making funny memes from his photos. Initially, he did not accept his new role, tried to fight it. It took several years to realize that what he could not change, had to be at the forefront of it. At the age of 72, he created a website for his fans. He started working to replace the not always positive message of the memes to carry a positive point of view. The basic idea of his philosophy, that is the smaller or bigger annoyances of life should not be taken too seriously, they should be overcome with a sad smile, resonated among young people. He already has more than half a million followers worldwide. The popularity gained in this way has changed his daily life. Through invitations, he visited many countries around the world from Siberia to South America. His previously more introverted personality became more open to public appearances. Keeping up with the events of the world, new technical possibilities and the way of thinking of young people mean a steady occupation for him. His history is one-off and unrepeatable, but it provides an example of the positive consequences a career change in old age.
\end{abstract}

Key words: carrier, life span, Hide the pain Harold, Hide the Pain philosophy 


\section{Bevezetés}

Bevezetőként talán nem érdektelen megemlíteni, hogy esetemben az időskori aktivitás családi örökség. Édesapám 83 évesen bekövetkezett haláláig folyamatosan dolgozott szaklektorként és fordítóként, tanár nagyapám pedig 82 éves korában megnyert egy pályázatot, amely a korszerü fizikatanítási módszerekről szólt.

Foglalkozásomat tekintve villamosmérnök vagyok, szükebb szakterületem a világítástechnika. Szakmai körökben a Világítástechnikai Társaság megválasztott elnökségi tagjaként, az Óbudai Egyetem meghívott előadójaként, számos hazai és külföldi publikáció szerzőjeként szereztem némi elismertséget, munkámat pályafutásom során több szakmai díjjal is elismerték.

\section{Egy új karrier}

Nyugdíjazásom utáni karrierem hétköznapi módon kezdődött, egy nyári vakációval, történetesen Törökországban. Talán nincs is olyan ember, aki ne akarná megörökíteni a nyaralási élményeit, én sem vagyok különb. Valamikor régen ezeket a fotókat családi körben és baráti társaságban mutogattuk egymásnak, ma már feltöltjük őket valamilyen közösségi oldalra, nem is gondolva arra, hogy ezek a fotók később a véletlenek sorozatának köszönhetően saját életre kelhetnek. Az én nyaralási képeim is eljutottak a barátaim, rokonaim mellett egy hivatásos fotóshoz, aki megkeresett azzal, hogy egy hozzám hasonló karakterü modellt keres, és szeretne rólam néhány próbafelvételt készíteni. Hízelgő volt a megkeresés, és igent mondtam a felkérésre. Elkészültek a képek, amik nemcsak a fotósnak, hanem nekem is tetszettek, az első próbafelvételeket további fotózások követték. Több száz felvétel készült, ezeken voltam orvos, tanár, családapa, sportoló, szerető férj, sőt még Mikulás is (1. ábra). Tudtam arról, hogy ezeket a stockfotónak nevezett képeket illusztrációként felhasználhatják különböző cikkekhez, reklámokhoz, nyomtatott és elektronikus kiadványokhoz, és hozzá is járultam a fotók ilyen célú használatához. Mindössze három olyan érzékeny területet jelöltem meg, ahol nem szerettem volna magamat viszontlátni a monitoron vagy nyomtatásban. Ez a három terület érthető módon a politika, a vallás és a szex volt. 


\section{1. ábra A legnépszerübb fotó, ami bármilyen képaláírást „elbír”}

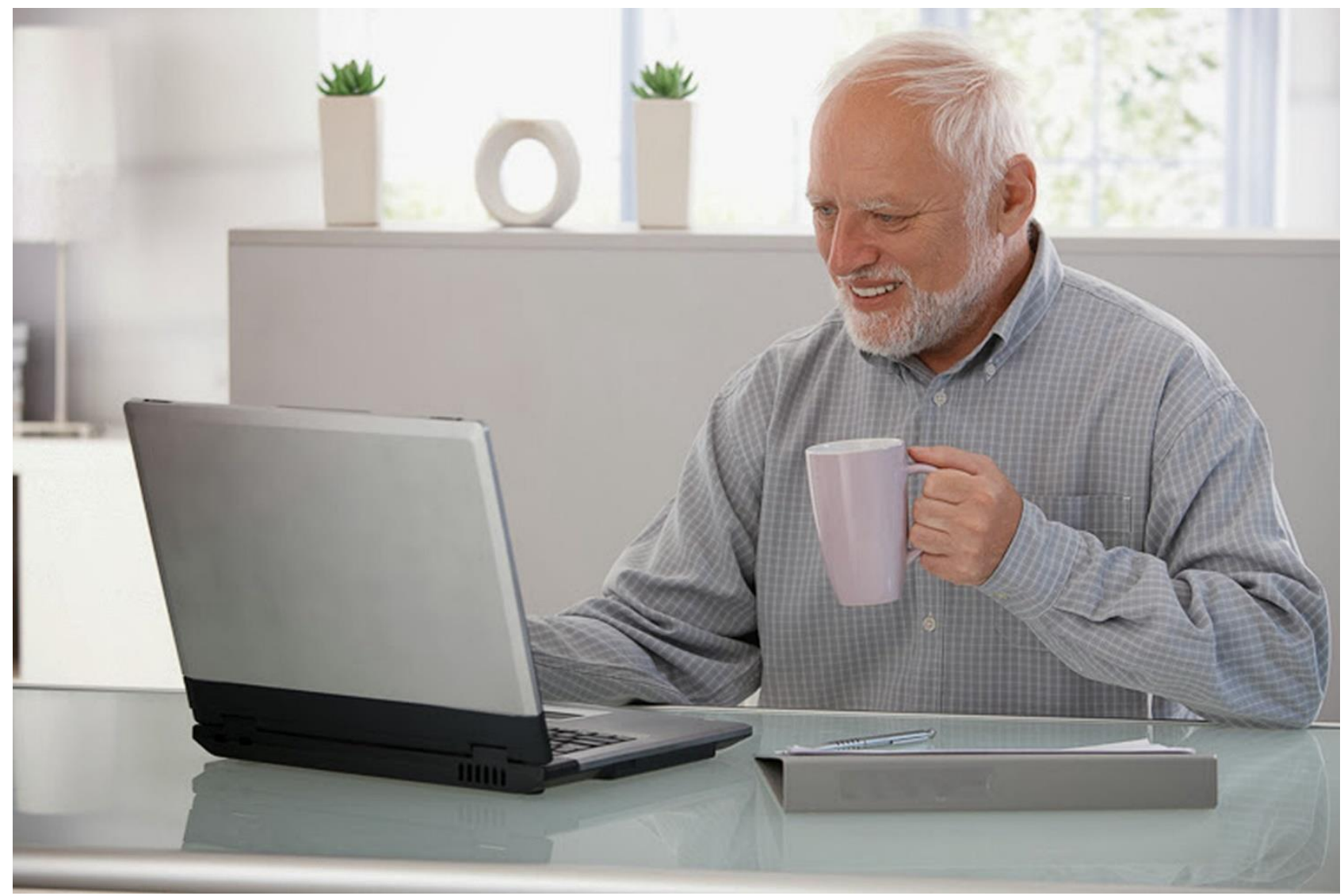

forrás: a szerzö tulajdona

Egy idő után kíváncsi lettem, hogy mire használják a képeimet. Elég volt néhány képkeresést lefuttatni, és megnyugodva vettem tudomásul, hogy tanárként egyetemi honlapokon, orvosként kórházi oldalakon láttam viszont magamat, és így tovább.

Igen ám, de amikor néhány hónap elteltével újra rákerestem a képeim sorsára, furcsa dolgokra lettem figyelmes, megjelentek az első mémek. Ha valaki még nem találkozott volna ezzel a szóval, a mém egyszerüen az internet segítségével terjesztett humoros tartalmat jelent. Kiderült, hogy valaki Amerikában összegyüjtötte a fotóimat, és valamiféle versenyt hirdetett meg az ismerösei között, hogy ki tud valami vicces szöveget vagy képi poént hozzátenni. Elég furcsa, sokkoló érzés volt magamat viccfiguraként viszontlátni, hirtelenjében nem is tudtam, hogy mitévő legyek. Nyilvánvaló volt, hogy a képek nem jogszerü módon kerültek bele ebbe a játékba, a viccek gyártói nem törődtek a politika, vallás és szexmentességgel sem, az elkészült mémek gyakran túllépték a jó ízlés határait.

Átgondoltam a lehetőségeket: az eredeti képeket visszavonni nem lehet, hiszen egyszer már írásban hozzájárultam a felhasználásukhoz, bár arról nem volt szó, hogy viccelődni fognak velem. A kalóz használat ellen nyilván fel lehet lépni, be lehet záratni azokat az oldalakat, ahol ilyent tapasztalok. Azzal azonban tisztában voltam, hogy ez csak ideiglenes megoldás lehet, hiszen be lehet ugyan 
záratni egy oldalt, de az internet nem felejt, akár már másnap három újat indíthatnak helyette, ugyanazzal a tartalommal. Így azután abban bíztam, hogy annyi új dolog jelenik meg naponta az interneten, hogy szép lassan elfeledkeznek rólam az emberek és senki nem lesz már kíváncsi a viccessé alakított képeimre.

Nagyot tévedtem. A képek terjedése nem állt meg, sőt egyre újabb országokat ért el ez a mánia. A legtöbb felvétel közben a fotós kérésére mosolyognom kellett, és az emberek úgy gondolták, hogy ez a mosoly nem volt igazán szívből jövő, valami rejtett szomorúságot, fájdalmat láttak mögötte. Nevet kaptam, elneveztek Hide the pain Haroldnak, vagyis a fájdalmát elrejtö Haroldnak. Amerika után Angliát, Franciaországot, Oroszországot, majd Magyarországot is meghódították a mémek, jelenleg talán Latin-Amerikában a legnépszerübbek a fotóim. Sokáig nem tudta senki, hogy valójában ki is a vicces képek főszereplője. Aztán egy orosz internet felhasználó valahogyan kinyomozta az elérhetőségemet, és elkezdett nyaggatni, mutassam meg, hogy egy valós, létező személy vagyok, mert nagyon sokan kételkednek ebben, úgy gondolják, hogy a képek valamiféle elektronikus manipuláció eredményeként születtek.

Először nem reagáltam rá, de végül eluntam a sok unszolást, nem maradt más számomra, minthogy kövessem a régi mondást: ha valamit nem tudsz megváltoztatni, akkor annak állj az élére. Első lépésként kitettem magamról egy fotót egy orosz közösségi oldalra, amin egy papírlapot tartok a kezemben ezzel a felirattal: Élek. Néhány óra alatt, ahogy mondani szokták, felrobbant az internet, százezrek látták ezt a képet és a médiában is híre ment a dolognak. Érdekes módon ennek egy váratlan és pozitív következménye lett, a bántó vagy sértő mémek szinte teljesen megszüntek.

Következő lépésként, immár 7 évvel az első fotók elkészítése után a külföldi követőkre gondolva létrehoztam egy angol nyelvü „rajongói” oldalt a Facebookon. Saját nevemben és magyarul már régóta jelen voltam a közösségi médiában, villamosmérnökként nem volt idegen számomra a számítástechnika és az informatika. Célul tűztem ki, hogy a rólam kialakult képet úgy alakítsam, hogy a közvetített üzenet pozitív tartalmat hordozzon. Hamarosan rájöttem azonban, hogy az új tartalmak előállítása, a követőkkel való kapcsolattartás nagyobb feladat annál, mint amit az íróasztalom mellett ülve egymagam is el tudok végezni. Most már egy olyan kis fiatal csapattal dolgozom együtt, akik tele vannak ötletekkel, értenek a technikai megvalósításhoz, és kellően rámenősek ahhoz, hogy felkutassák a szereplési lehetőségeket. Eljutottunk odáig, hogy a követőim száma világszerte meghaladja a félmilliót. Rendszeresen kapok külföldi meghívásokat, Szibériától Dél-Amerikáig beutaztam a világot. Persze ebben a karanténos időszakban nagyon sok meghívást le kellett mondanom, viszont az így megnövekedett szabadidőt kihasználva belefogtam az életemről szóló könyv megírásába. 


\section{A ,Hide the pain” filozófia}

Elég lehet egy furcsa arckifejezés ehhez a sikertörténethez?

Biztos hogy nem, kell valami több is, amit jobb híján „Hide the pain” filozófiának neveztem el. Naponta érnek bennünket kisebb-nagyobb bosszúságok, amiket nem szabad túl komolyan venni. Vágjunk jó képet hozzá, még akkor is, ha fáj, és mindjárt elviselhetőbb lesz az élet. Nagyon sok személyes üzenetet kapok, a legtöbben azt írják, hogy szeretik, amit csinálok, folytatásra biztatnak és megköszönik azt az életszemléletet, amit az üzeneteim közvetítenek. Végső soron a karakter, amit rám osztott az internet népe, vagyis az, hogy rejtsük egy mosoly mögé, ha valami szomorúság ért, teljességgel elfogadható. Szerepjáték ugyan, de Shakespeare-től tudjuk, hogy színház az egész világ, és színész benne minden férfi és nő. Az én szerepem az lett, hogy most Hide the pain Haroldot alakítsam. Olyan szerepjáték, ami megváltoztatta, érdekesebbé tette az életemet. Korábban jobban szerettem a háttérben maradni, mint a reflektorfényben állni, most nyugdíjasként hozzá kellett szoknom, hogy sokszor felismernek az utcán, meghívnak különböző rendezvényekre, elhívnak fotózni vagy videót forgatni. Követőim az életkori megoszlás tekintetében leginkább az egyetemista korú, 18 és 24 év közötti korosztályba tartoznak (2. ábra). Naponta elöfordul, hogy ismeretlen fiatalok állítanak meg az utcán egy közös fotó vagy csak egy kézfogás erejéig.

\section{2. ábra A követők életkor és nem szerinti megoszlása}

\section{Célközönség}

\section{Életkor és nem}

$\begin{array}{ll}\text { Férfiak } & 74.10 \% \\ \text { Nốk } & 25.90 \%\end{array}$

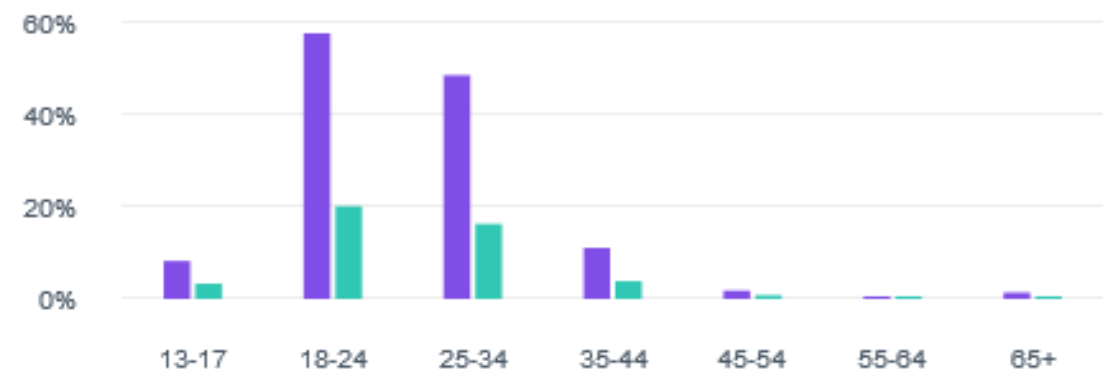

forrás: saját szerkesztés 
A világ eseményeivel, az újabb technikai lehetőségekkel, a fiatalok gondolkodásmódjával való lépéstartás állandó elfoglaltságot jelent számomra, nem engedi, hogy ellustuljon a gondolkodásom. Olyan, tőlem idegen területeken is kipróbálhattam magam, mint a színjátszás, az ének, a tánc, vagy az extrém sportok.

\section{Konklúzió}

Tudom, hogy a történetem egyszeri és megismételhetetlen, de talán példát mutat arra, hogy egy időskori totális karrierváltásnak milyen pozitív következményei lehetnek. Befejezésül tanulságként azt emelném ki, hogy idősebb korban is nyitottnak kell lenni az élet által felkínált olyan új lehetőségekre, amelyek távol állhatnak mindattól, amivel korábban foglalkoztunk. 